\title{
Assédio moral na escola: insulto e desejo de reparação moral em uma instituição escolar do Distrito Federal brasileiro
}

Moral harassment at school: insult and desire for moral reparation at a Brazilian Federal District's educational institution

\section{Thaisa Marilia Coelho Tiba}

\section{(2) OpenEdition Journals}

\section{Edição electrónica}

URL: https://journals.openedition.org/aa/8348

DOI: $10.4000 / a a .8348$

ISSN: $2357-738 X$

\section{Editora}

Programa de Pós-Graduação em Antropologia Social (UnB)

\section{Edição impressa}

Paginação: 288-303

ISSN: 0102-4302

\section{Refêrencia eletrónica}

Thaisa Marilia Coelho Tiba, «Assédio moral na escola: insulto e desejo de reparação moral em uma instituição escolar do Distrito Federal brasileiro», Anuário Antropológico [Online], v.46 n.2 | 2021, posto online no dia 30 maio 2021, consultado o 01 junho 2021. URL: http://journals.openedition.org/aa/ 8348 ; DOI: https://doi.org/10.4000/aa.8348

\section{(c) (i) (9)}

Anuário Antropológico is licensed under a Creative Commons Atribuição-Uso Não-Comercial-Proibição de realização de Obras Derivadas 4.0 International. 


\title{
anuário antropológico \\ $v \cdot 46 \cdot n^{\circ} 2 \cdot$ maio-agosto $\cdot 2021.2$
}

\section{Assédio moral na escola: insulto e desejo de reparação moral em uma instituição escolar do Distrito Federal brasileiro}

Moral harassment at school: insult and desire for moral reparation at a Brazilian Federal District' s educational institution

DOI: https://doi.org/10.4000/aa.8348

\author{
Thaisa Marilia Coelho Tiba \\ Secretaria de Estado de Educação do Distrito Federal, Brasília, DF, Brasil \\ Professora de Ciências Sociais no Ensino Médio da Secretaria de Estado de Educação do Distrito Federal, \\ Brasília, Distrito Federal, Brasil. Mestra em Antropologia Social pelo PPGAS/DAN/UnB. Tem interesse nos \\ seguintes temas: assédio moral no trabalho, moralidades, política e violência.
}

thaisamarilia.tiba@gmail.com

Este artigo apresenta os desdobramentos de uma etnografia do assédio moral entre um grupo de professores da educação básica do Distrito Federal brasileiro. Partindo das vivências dos interlocutores de uma pesquisa realizada em 2013, considerei que as palavras e gestos que assediam estão inseridos em um jogo de linguagem específico, 0 do assédio moral. Por meio da retomada da análise das narrativas de uma das interlocutoras, a professora Rosa, constatei que tais ações constituem um insulto moral sistemático, cuja influência sentida por ela gera a dor e o sentimento de ressentimento, que enseja o desejo da reparação moral. Além disso, a história de Rosa demonstra que as ações de assédio moral observadas entre alguns professores da capital administrativa do país se encontram inseridas na gramática da política local e constituem uma ferramenta utilizada nas disputas políticas por espaços e poderes institucionais.

Assédio moral. Insulto moral. Sofrimento. Reparação moral. Política.
This article depicts the developments of an ethnography of moral harassment within a group of basic education teachers from the Brazilian Federal District. Based on the experiences of the interlocutors of research carried out in 2013, I considered that the harassment words and gestures are part of a specific game of language, the game of moral harassment. Through the resumption of the analysis of the narratives of one of these interlocutors, teacher Rosa, I have verified that these actions are a systematic moral insult, whose influence felt by her causes suffering and the feeling of resentment, which generates the desire for moral reparation. Furthermore, her story demonstrates that the actions of moral harassment observed among some teachers of the capital city are included in the grammar of local politics and constitute an instrument often used in political feuds for institutional spaces and influence.

Moral harassment. Moral insult. Suffering. Moral reparation. Politics. 
"meu caminho não diz respeito a ir adiante, mas a retornar, a coligir palavras e pensamentos, mediante os quais, penso eu, se forjaram as ligações entre mim e meus interlocutores no campo." (Veena Das, 2020)

Final do mês de maio, o clima estava ameno. Estávamos em frente a um prédio de concreto, o verde da vegetação ao redor e o vazio completavam a composição da paisagem. O único movimento era o de entrar e sair do prédio. Diante das edificações monumentais de Brasília, incluindo os seus palácios ${ }^{1}$, acostumei-me a pensar nos trabalhadores que as construíram e nos dilemas vivenciados pelos "candangos". Aquele espaço, assim como outros do Distrito Federal, acolheriam as narrativas dos professores da educação básica sobre assédio moral no ambiente de trabalho.

O prédio era o da Biblioteca Central da Universidade de Brasília, situada no campus Darcy Ribeiro, em Brasília. Anísio Teixeira e Darcy Ribeiro foram os idealizadores do inovador projeto educacional da nova capital do Brasil. Desde a década de 1960, milhares de professores vêm convivendo nas escolas classe, escolas parque e nos centros de ensino fundamental e médio do Distrito Federal. Às intenções iniciais desses dois idealizadores, acrescentam-se os desafios estruturais, a conjuntura histórica e as práticas dos diferentes grupos sociais, que juntos compõem o dinâmico cotidiano das escolas vivenciado pelos professores da educação básica (Holston, 1993, p. 20).

Em frente à biblioteca, o assunto em pauta era assédio moral no trabalho. Era a primeira vez que eu conversava com este professor de Sociologia de um centro de ensino médio situado no Plano Piloto. $O$ tom da sua voz era bem baixo; algumas vezes, ele o aumentava em decorrência dos sentimentos de indignação e impotência, ato o qual era acompanhado de um olhar firme e temeroso com relação à palavra dita e aos seus efeitos. Sua palavra era contida e o tom aflito expressava a gravidade do assunto. A ideia compartilhada por nós dois era a da evitação: esta estivera presente no contato telefônico no qual a expressão "assédio moral" fora pronunciada pela primeira vez e dera início a uma interlocução sobre o assunto entre professores da educação básica do Distrito Federal brasileiro. Era desejado e necessário falar sobre o assédio sofrido, mas deveríamos fazê-lo com parcimônia.

Estávamos em 2013, momento em que iniciei a busca por possíveis interlocutores sobre a questão do assédio moral vivenciado por esses profissionais. Nos primeiros contatos telefônicos, ao mencionar a expressão "assédio moral", as reações foram desde a aceitação duvidosa à rápida negativa, externalizada com um "não, esse assunto não me interessa mais".

A afinidade com a expressão "assédio moral" me aproximou de parte dos meus interlocutores. Nesse contato inicial, da aproximação até a conversa, da conversa até a descrição dos atos, que eram denominados como "assédio moral" por cada um deles, ela foi o denominador comum, e o foi também na elaboração de uma etnografia sobre a temática (Tiba, 2014).

Este texto apresenta os desdobramentos dessa etnografia sobre o assédio mo-
1 Dispostos em ordem alfabética: Palácio da Alvorada, Palácio do Buriti, Palácio do Itamaraty, Palácio do Jaburu e Palácio do Planalto. 
ral entre professores do ensino básico da capital federal. Por meio da retomada de momentos vivenciados por meus interlocutores, sobretudo por uma das interlocutoras, estabeleço um diálogo entre Filosofia e Antropologia, a fim de elaborar uma interpretação sobre as indeléveis ações do assédio moral nas escolas do Distrito Federal.

\section{Apresentando a etnografia sobre assédio moral}

Entre 2005 e 2019, trabalhei como professora da educação básica em três regiões administrativas do Distrito Federal: Ceilândia, Paranoá e Plano Piloto. O ano de 2007 foi o momento no qual comecei a ouvir algumas narrativas sobre indisposições entre professores no ambiente escolar. Nesse momento, os relatos alheios sobre os sofrimentos gerados por tais indisposições eram escutados, mas não "acessados", uma vez que eu ainda não tinha condições para percebê-los com clareza. Faltava um conector entre essas narrativas e o vivenciado no cotidiano escolar.

Alguns anos depois, fui diretamente "afetada" pelo assédio moral no ambiente escolar. Segundo Jeanne Favret-Saada, deixar-se afetar consistiu em um dispositivo metodológico necessário para ter acesso à bruxaria na região do Bocage, França (Favret-Saada, 2005, p. 155). Por meio dos afetos, estabeleci a conexão entre as narrativas sobre "indisposições no ambiente de trabalho" até então escutadas e a expressão "assédio moral”. Um universo de relações se descortinou e me permitiu adentrar no jogo de linguagem (Wittgenstein, 1999) do assédio moral presente nessa instituição educacional. $O$ desejo de compreender esse intrincado universo de relações deu origem a um projeto de pesquisa sobre a temática. Por meio dos afetos compartilhados nesse espaço de trabalho, fui situada entre os que ressentem as ações de assédio moral, de modo que abordei nesta etnografia sobre essa forma de violência (Tiba, 2014), sobretudo, os olhares e vozes dos que apresentaram queixas sobre o assédio moral sofrido nas escolas.

A viabilização deste trabalho deu-se a partir da pesquisa documental e das entrevistas realizadas no ano de 2013, com 39 professores das regiões administrativas de Ceilândia, Guará, Paranoá, Planaltina, Plano Piloto e São Sebastião envolvidos nas queixas sobre assédio moral, tanto os que as apresentaram, quanto aqueles que foram implicados nos conflitos e os que realizaram a mediação institucional entre as partes envolvidas. Dentre estes, 24 apresentaram queixas sobre o assédio moral vivenciado nas escolas do Distrito Federal - 14 professoras e 10 professores atuantes nos Ensinos Fundamental e Médio. Procurei registrar ao máximo esses momentos com as interlocutoras e os interlocutores objetivando apreender os meandros do assédio nessa instituição educacional bem como acompanhar o maior número de eventos nos quais a temática da docência na educação básica e relações de trabalho estivessem em debate, como os promovidos pelas entidades sindicais.

A partir de uma prévia sensibilização sobre educação escolar em contextos bilíngues e multilíngues em território brasileiro (Cavalcanti, 1999), sobre educação escolar indígena e Antropologia (Silva, 2001) e sobre o método de investigação 
observacional participativa interpretativa dos processos de ensino e aprendizagem (Erickson, 1986, p. 196), realizada por meio de um diálogo entre a Linguística Aplicada e a Antropologia, que despertou minha atenção para as conexões estabelecidas entre educação escolar, alteridade, linguagem e relações de poder, considerei as palavras e gestos de assédio moral como componentes de um jogo de linguagem específico responsável pela exclusão de alguns professores no e do ambiente escolar. Baseando-me na perspectiva crítica da análise do discurso (Fairclough, 1989), procedi ao estudo das entrevistas realizadas e dos registros sobre as interações cotidianas envolvendo assédio moral entre professoras e professores da educação básica do Distrito Federal, contextualizando-as no texto da cultura local.

Como resultado desta pesquisa, constatei que o assédio moral entre grupos de professores da educação básica da capital federal consistia em uma perseguição sistemática no ambiente de trabalho por meio de um insulto moral sistemático (Tiba, 2014, p. 46). As ações de assédio moral observadas em meio às disputas envolvendo os diferentes grupos de professores da escola possuíam as seguintes motivações: uma resposta aos discursos dissonantes e críticos à instituição em questão por parte de alguns profissionais, as divergências sobre o que viriam a ser direitos e privilégios nas disputas cotidianas observadas entre estes grupos e os conflitos em torno das expressões da diversidade sociocultural dos profissionais da educação básica. Observei que uma das consequências do assédio moral sofrido por tais professores foi o adoecimento físico e psicológico (Tiba, 2014, p. 213-216).

Entre os anos de 2014 e 2019, a elaboração do conhecimento antropológico so-

bre o assédio moral nessa instituição educacional do Distrito Federal foi realizada por meio das vivências no campo e do emprego das seguintes técnicas de pesquisa: "deixar-me afetar" pelas ações de assédio moral, pelos registros da participação observante e pelas conversas cotidianas sobre a temática. Partindo do pressuposto de que o conhecimento possui o movimento similar ao de uma espiral, consegui nesse ínterim rever alguns entendimentos e aprofundar outros, dada a generosa ação do tempo e do que considero ser um necessário distanciamento espacial do campo após anos de imersão neste. Ao revisitar esta etnografia, apresento os seus desdobramentos, que resultam desse movimento em espiral do conhecimento. Para tanto, irei me deter nas vivências de uma das interlocutoras desta pesquisa, pelos motivos que serão apresentados nos tópicos a seguir.

\section{O nome dado: assédio moral}

Em 2012, momento em que iniciei a pesquisa sobre o assédio moral entre professores atuantes no ensino básico do Distrito Federal, que era formado à época pelo Plano Piloto e outras 30 regiões administrativas, a expressão "assédio moral" já circulava nas entidades sindicais de diferentes categorias laborais do Distrito Federal por meio das cartilhas de sensibilização sobre a temática. Além disso, instituições estatais como o Ministério da Saúde também veiculavam seus materiais informativos. Posteriormente, em 2014, a campanha contra o "Assédio moral e sexual no trabalho" era vista no metrô do Distrito Federal. Ou seja, a expressão "as- 
sédio moral" circulava no Planalto Central da Esplanada dos Ministérios ao Setor de Indústrias Gráficas, da Estação Central às estações Ceilândia e Samambaia. Já entre os meus interlocutores, o termo continuava a ser pronunciado com cuidado, um sussurro incômodo junto a um olhar atento quando no ambiente escolar, ou repleto de emoções e acompanhado por um olhar aflito quando a conversa era realizada em outro local. Não se tratava de um grande circular, mas a expressão "assédio moral" circulava entre os professores da educação básica.

Essa movimentação foi acompanhada da sensibilização sobre a temática pelos meus interlocutores. Diante da confusão mental gerada pelas ações de assédio moral e por seu caráter inefável, nomear tais atos constituiu o primeiro passo para a sua materialização. A frase proferida pela professora de Filosofia Flora, conhecida que enfrentara o assédio moral em um centro de ensino médio do Plano Piloto em meados do ano 2013, expressa bem a importância de nomear. Segundo ela: "Eu li a cartilha [sobre assédio moral entre professores da educação básica publicada pelo Sindicatos dos Professores] e consegui perceber o que estava acontecendo comigo".

Em meio às angústias da incompreensão do que se passava e da impressão compartilhada por essa professora, referente a um sofrimento solitário, o nome dado foi o responsável por uma nova relação com o cotidiano. Em Investigações filosóficas, Ludwig Wittgenstein afirma que o nome dado a algo, o que o designa, é uma espécie de etiqueta ${ }^{2}$ veiculada nos jogos de linguagem. Ao identificar que as ações difusas e sutis, as quais geravam desconforto, medo e sofrimento no ambiente de trabalho, eram denominadas "assédio moral", ela passou a compreendê-las.

Segundo Wittgenstein, para ser entendido, é preciso que o conceito seja definido com precisão. A definição de "assédio moral no trabalho" apresentada pela psicanalista francesa Marie-France Hirigoyen era a que circulava no Distrito Federal em 2013. Segundo Hirigoyen:

Por assédio moral no trabalho temos que entender toda e qualquer conduta abusiva manifestando-se, sobretudo, por comportamentos, palavras, atos, gestos, escritos que possam trazer dano à personalidade, à dignidade ou à integridade física e psíquica de uma pessoa, pôr em perigo o seu emprego ou degradar seu ambiente de trabalho (Hirigoyen, 2009, p. 65).

Presente nas cartilhas de sensibilização veiculadas nessa região, como a $A s$ sédio Moral. Assédio: violência e sofrimento no ambiente de trabalho, publicada pelo Ministério da Saúde em 2008, e nos corredores institucionais, a expressão "assédio moral" acompanhada da definição de Hirigoyen pode ser considerada um ideoscape sobre o direito à integridade física, psíquica e moral no ambiente de trabalho (Appadurai, 2002, p. 53), que circulava em meio às fricções (Tsing, 2005, p. 05) geradas pelo confrontar-se com os diferentes interesses e instituições nas quais esteve presente.

Considerando que as palavras são utilizadas em meio a jogos de linguagem
Wittgenstein, Investigações filosóficas, parágrafo 15 . 
e que seus significados devem ser contextualizados, constatei que, entre os professores da educação básica do Distrito Federal, a expressão "assédio moral" era utilizada para designar a perseguição sistemática no ambiente de trabalho por meio de palavras, gestos e ações. Além disso, embora o termo expresse a natureza do assédio sofrido, é importante ressaltar qual é o assédio em jogo: um cujas ações são motivadas pelo embate entre moralidades, as quais são acionadas cotidianamente nos conflitos e disputas no ambiente escolar. Como esperado, observei que, dado o seu caráter persecutório, não era usual pronunciar a expressão no ambiente escolar, já que gerava desconforto entre alguns professores da educação básica. Mais do que isso, os cuidados ao pronunciar "assédio moral" demonstravam uma interdição: a proibição de manifestar publicamente essa acusação sobre os profissionais da educação básica.

\section{Assédio moral na escola: insulto moral entre professores da educação básica}

Assim como o apresentado na epígrafe de Veena Das, meu caminho neste texto consiste em retomar as palavras, gestos e pensamentos dos meus interlocutores para tecer as considerações sobre o assédio moral entre alguns professores da educação básica. Mais do que isso, trata-se, como explicitado pela autora da epígrafe, de atentar para a maneira com que essas palavras e ações estabeleceram ligações entre mim e meus interlocutores.

Dentre as minhas interlocutoras, há uma professora que há certo tempo vem refletindo sobre a temática do assédio moral no trabalho. Possuidora de grande vivência em meio aos professores da educação básica, o diálogo com ela e suas reflexões me ajudaram a elucidar o assédio moral tanto em termos institucionais como individuais. A singularidade de sua história, a forma como ela articula as diferentes esferas da instituição à qual é vinculada e outras externas, bem como as suas vivências nas escolas do Distrito Federal, são cruciais para a reflexão sobre o assédio moral entre professores da educação básica.

Em meio ao convívio cotidiano em um centro de ensino médio localizado no Plano Piloto, o afeto nos aproximou. Estabelecemos e possuímos uma relação amistosa. Convivi com esta professora por um tempo maior do que o partilhado com os demais professores que apresentaram queixas sobre o assédio moral, e acompanhei grande parte de um ciclo da sua vida. Além das entrevistas realizadas com minha interlocutora, foram inúmeros os momentos de diálogos sobre as vivências pedagógicas e relacionais no ambiente escolar, incluindo a temática do assédio moral, e a participação observante no seu ambiente de trabalho.

Minha interlocutora é uma mulher de meia idade e não é natural do Distrito Federal. Viera para Brasília cursar a graduação e escolheu essa cidade para viver. Professora da área de Ciências Humanas, dotada de carisma e conciliadora, conseguia agregar os demais professores ao trabalho pedagógico. Seu nome era Rosa.

Por se tratar de uma expressão incômoda no ambiente escolar, as narrativas sobre assédio moral foram ficcionalizadas para resguardar a identidade da inter- 
locutora, não a indispondo institucionalmente e com os demais professores da educação básica.

Longe da escola, nas caminhadas entre as superquadras do Plano Piloto, em meio aos pilotis e gramados, Rosa contava as histórias do assédio moral vivenciado no trabalho. Com o semblante cansado, as palavras eram ditas aos poucos, seguidas de uma pausa para respirar e refletir sobre o que dissera. A amplitude do espaço dava vazão às narrativas até então represadas, mas as palavras gotejavam lentamente. $\mathrm{O}$ medo dos efeitos da palavra dita cerceava os movimentos de Rosa. O céu, comumente azul, ficava cinza.

Ao relembrar as cenas de assédio moral na escola, Rosa retoma o seguinte momento:

Ela chegava mais próximo e falava sempre baixinho. Não me considerava apta para exercer aquela atividade e sempre me indispunha com os outros. Eu tive consciência de que ela fazia isso quando um dia a ouvi dizer para o responsável por um estudante que não havia ninguém para atender a sua demanda naquele momento, uma vez que não havia coordenadora pedagógica na escola àquela hora. Eu estava lá, bem atrás dela. Você pode me perguntar se eu não estava enganada ou com mania de perseguição. Não. Um dia, uma professora novata na escola me perguntou se eu era ou não a coordenadora pedagógica, pois a diretora a havia convidado para compor a equipe da coordenação pedagógica. Essa professora compartilhou isso comigo e não entendeu bem o que estava acontecendo. Porque a diretora sempre falava baixinho, ninguém percebia todas as suas ações, achavam que eu estava enganada, mas eu sabia o que estava acontecendo.

No trecho acima, Rosa apresenta um dos episódios centrais para a tomada de consciência sobre o assédio moral sofrido na escola. A afirmação da diretora "a coordenadora não está, venha em outro momento" é percebida por Rosa, que ali estava, como um ato de desconsideração à sua identidade como coordenadora pedagógica, sendo que ela havia sido escolhida para exercer essa função e referendada pela maior parte dos professores.

Uma pausa elucidativa para compreender o jogo de linguagem do assédio moral. Assim como as situações hipotéticas apresentadas por Wittgenstein para refletir sobre a linguagem, o trecho a seguir elucida o contexto em que a frase foi dita. Imagine a seguinte situação: você está na escola, já cumprimentou a diretora com um "bom dia" e, no meio da manhã, a surpreende dizendo para o responsável por uma estudante: "a coordenadora não está, venha em outro momento". Segundo Wittgenstein, a significação da palavra reside em seu emprego. A relação entre o sentido da palavra e as regras do jogo no qual está inserida se dá por meio da práxis diária do jogo ${ }^{3}$. Se para um observador externo, essa frase poderia expressar a distração ou o equívoco da diretora, para Rosa esse foi o momento de "cair a ficha" e ter consciência da ação de desconsideração a que vinha sendo submetida. Palavras e gestos que, em meio ao jogo de linguagem local, realizam
3 Wittgenstein, Investigações filosóficas, parágrafo 197. 
um ato de assédio.

Em decorrência da dubiedade das ações que assediam, Rosa, assim como Flora, demorou para compreender que se tratava de assédio moral no ambiente de trabalho. Tal dubiedade, que faz parte do jogo de linguagem dessa forma de violência, gera confusão mental em quem está sujeito a essas ações, fazendo-o oscilar em seus julgamentos sobre si mesmo, gerando um sentimento de insegurança.

Para Rosa, ao indispô-la com os responsáveis pelos estudantes e até mesmo com os estudantes, a diretora fomentava um ambiente de trabalho desfavorável para ela, o que a deixava insegura e a desgastava psicologicamente. Ao ter consciência dos atos de desconsideração, Rosa percebia a frágil condição em que se encontrava na escola: sujeita às ações de assédio moral, sabia que as palavras poderiam se voltar contra ela e que não teria o respaldo institucional para resolver mal-entendidos ou conflitos. Sentia medo das palavras e dos atos administrativos que, propositalmente, poderiam comprometê-la institucionalmente. Por se tratar de assédio moral, tinha consciência de quão difícil seria obter o apoio dos demais professores perante um embate com a direção escolar.

As palavras que assediam e promovem a desconsideração da identidade de Rosa como coordenadora pedagógica são vistas como um insulto moral. Segundo Luís Roberto Cardoso de Oliveira, trata-se de um insulto caracterizado pela difícil apreensão material e pela desvalorização ou negação da identidade do outro (Cardoso de Oliveira, 2008, p. 135-136). O insulto moral, por ser velado, assemelha-se a um furto, que vai levando aos poucos pequenas porções do ser, porções da substância moral das pessoas dignas (Cardoso de Oliveira, 2011, p. 149), fragilizando pessoas como Rosa publicamente.

Assediada pela violência das palavras e dos gestos que maltratam, a professora sabia que dificilmente alguém apreenderia em sua totalidade as palavras e gestos direcionados contra ela cotidianamente. Tais ações, intencionalmente dirigidas a ela pela diretora e por alguns professores, geravam um sentimento de ressentimento (Cardoso de Oliveira, 2011, p. 114) que pertencia somente a ela. Decorria-se daí a sua solidão no sofrer e no enfrentamento do assédio moral.

\section{0 assédio da Rosa: as motivações do assédio que é moral}

Acho que muita coisa começou quando saí em defesa de uma professora, que tinha acabado de chegar à escola. Era começo do ano letivo, aquele momento em que todos retornam para a escola e os novatos chegam. Semana pedagógica. Quando ela chegou, como não fazia parte do grupo, queriam que ela não concorresse, na distribuição de carga horária, à vaga em um projeto interdisciplinar. Eu disse para ela que não, que ela tinha direito, já que tinha vindo pela remoção dos professores e o projeto era da escola. Foi a partir daí que a relação de perseguição começou a ficar mais assim e a tentativa de me retirar da escola, mais evidente.

Autônoma. Essa era a palavra que expressava a maneira de ser de Rosa. Con- 
tava com orgulho e os olhos brilhantes as histórias do tempo do curso de graduação, do engajamento com o movimento estudantil e das contestações com um ou outro representante do Centro Acadêmico. Nas narrativas sobre as vivências nas escolas onde trabalhara, deixava claro que costumava se envolver animadamente nos debates pedagógicos e naqueles relacionados à convivência escolar.

Então, diante de uma situação embaraçosa envolvendo uma novata na escola, acabou se indispondo com parte do grupo de professores. Um impasse moral. Rosa sabia que as regras vigentes na instituição respaldavam a professora novata, mas sabia também que as práticas na escola eram outras. Acreditando que o correto era orientá-la a posicionar-se e disputar a vaga no projeto da escola, Rosa assim o fez. Conhecia, mas não concordava com as motivações dos demais professores, que queriam que a novata desistisse de concorrer àquela vaga.

Por não compactuar com o grupo de professores que consentia com as práticas locais, fora "deixada de lado" e não conseguira ser admitida por ele. Nos momentos de acirramento das disputas, em que o assédio moral era sentido por ela com maior intensidade, costumava afirmar que o seu erro havia sido não ter se calado e compactuado com aqueles professores naquele momento.

Em suas falas, Rosa demonstrava uma reflexão incessante sobre as possíveis motivações do assédio moral sofrido. As acusações que o geraram nunca foram diretamente dirigidas a ela. Sentia, em decorrência da sequidão no tratamento, intercalado com os momentos de trégua, que havia feito algo errado. $\mathrm{O}$ "fazer algo errado", em termos morais, e o assédio por meio das palavras eram uma forma de o grupo relembrar o "mal feito", assim como nos casos das fofocas presentes nas disputas entre os Montenegrinos, no leste europeu. Segundo Cristopher Boehm, nesse contexto, a fofoca atua como uma espécie de corte, que relembra continuamente o grupo sobre as ações moralmente aceitáveis ou inaceitáveis (Boehm, 1984, p. 82-85). Do mesmo modo, ao discorrer sobre a fofoca em uma vila de ocupação em Porto Alegre, Cláudia Fonseca afirma que ela possui uma função educativa, uma vez que, por meio das histórias compartilhadas, os mais jovens aprendem as regras morais dos grupos sociais (Fonseca, 2004, p. 23). Já na instituição em questão, nos casos em que o assédio moral é realizado pelos estudantes, há uma inversão de papéis, e os estudantes adolescentes ensinam os valores morais locais por meio das palavras e gestos assediantes aos professores não iniciados.

Rosa quebrara a regra vigente, que consistia em compactuar com o grupo de professores na decisão sobre a quem caberia ocupar a vaga do projeto da escola. Assentir com as práticas estabelecidas por meio do seu silêncio e não as expor fazia parte do moralmente aceitável pelo grupo de professores envolvidos na disputa e nas regras da gramática da política local. Seria também uma forma de respaldar o grupo tal como se apresentava bem como as suas prerrogativas. Acreditava que, ao consentir com as práticas vigentes, fortaleceria as relações de reciprocidade, ampliaria as demonstrações de apreço e contaria com o apoio do grupo diante dos contratempos cotidianos enfrentados pelos professores da educação básica.

Poderia, mas é importante considerar que nesse contexto as afinidades são eletivas e as esferas do parentesco e da política se encontram associadas (Weber, 
2011, p. 83). O grupo de professores, que decidia os rumos da escola, possuía maior afinidade com outra professora, a qual almejava trabalhar com esse grupo, e gostaria de vê-la ocupando a vaga que até então era de Rosa. Segundo ela, ao sair da escola, aumentariam as possibilidades da movimentação da professora com quem aqueles simpatizavam para a vaga até então ocupada por ela.

Como os grupos de professores e as disputas são diversos, o embate era sobre uma vaga que poderia fortalecer aqueles que, informalmente, dirigiam a escola. Angariar apoio, expresso por meio do respaldo ao projeto pedagógico e às demais decisões desses professores, era importante, uma vez que são muitos os conflitos cotidianos. No Distrito Federal, sede da capital administrativa do país, a escola manifesta diversas disputas do jogo político, como entre as diferentes perspectivas educacionais que se farão presentes em seu cotidiano. Escrever um projeto político pedagógico ou uma proposta pedagógica são atividades imbuídas de significados distintos para os professores atentos aos meandros da tecedura das relações sociais cotidianas na escola.

Essas e outras disputas estão presentes na rotina dos professores da educação básica do Distrito Federal. Nesse sentido, é importante se atentar para o fato de que o assédio moral sentido à flor da pele por alguns desses professores era uma manifestação da disputa política e da competição dos grupos nas escolas, que estavam inseridas na gramática da política do Distrito Federal (Das, 2020, p. 148). As ações de assédio moral expressam uma faceta da sociabilidade dificilmente apreendida pelos não iniciados nessa gramática política. Trata-se de uma violência inefável inscrita em uma sociabilidade ${ }^{4}$ na qual a ocupação do espaço (incluindo o espaço institucional), acompanhada de seus significados, e a política estabelecem uma relação intrínseca. Tal relação é observada na instituição educacional em questão através das disputas travadas por espaços pelos diversos grupos no transcorrer das gestões à frente dessa instituição. Antonádia Borges atenta para o fato das disputas por cargos por meio do "emprego na política" serem marcadas por embates entre diferentes grupos de interesses observados na sede da região administrativa do Recanto das Emas, no Distrito Federal (Borges, 2003, p. 46).

Desse modo, assim como a fofoca e os rumores ${ }^{5}$, a palavra que assedia moralmente tem um efeito prático que é utilizado nas disputas políticas. Tratando-se de um insulto moral, a palavra direcionada ao outro é dotada da intenção de machucá-lo, o que gera o sentimento de ressentimento em quem está sujeito a esse insulto (Cardoso de Oliveira, 2011, p. 114). Além disso, as ações de assédio moral são geralmente acompanhadas dos sentimentos de desprezo ou raiva por parte de quem as realiza em decorrência das divergências políticas, dos embates entre as moralidades e dos conflitos em jogo. Esses sentimentos potencializam o ressentimento gerado pela violência das ações de assédio moral presente nas disputas cotidianas observadas entre alguns professores da educação básica do Distrito Federal.
$4 \quad \mathrm{Na}$ análise apresentada sobre os episódios de violência após o assassinato da primeira-ministra Indira Gandhi, Das afirma que: "A violência extrema que vimos era contígua à violência cotidiana, que implicou Estado e comunidade e demonstrou claramente que a violência não estava separada da socialidade: ao contrário, a agência da violência fez da socialidade uma entidade a ser 'produzida', não a que foi dada. Mais uma vez, dizer que a violência extrema era contígua à vida não significa dizer que eram a mesma coisa, mas que o cotidiano fornecia as bases a partir das quais o evento podia ser cultivado" (Das, 2020, p. 204).

5 Sobre a fofoca em uma área de ocupação em Porto Alegre (RS), Fonseca afirma que: "a fofoca envolve, pois, os relatos de fatos reais ou imaginados sobre o comportamento alheio. Ela é sempre concebida como uma força nefasta, destinada a fazer mal a determinados 


\section{A dor da Rosa: sofrimento gerado pelo assédio moral}

Nas conversas com Rosa, o retomar das memórias do assédio moral sofrido era acompanhado de gestos de apreensão e de palavras entrecortadas por um breve silêncio. Rosa mantinha o olhar baixo e as mãos procurando por algo para conter a ansiedade gerada por aquele momento. A palavra represada expressava a dor do trazer à tona a violência vivenciada. Em alguns momentos, houve pedidos de desculpas por não conseguir falar muito sobre o assunto.

Segundo Das, a memória e o tempo realizam os seguintes movimentos: o de translação, no qual a memória dá uma volta em torno da experiência e contrai mais ou menos a experiência sobre o vivido, e o de rotação, no qual a experiência dá uma volta em torno de si mesma e atenta para o mais útil (Das, 2020, p. 140). Ao relatar o assédio moral vivenciado na escola, as atitudes de desconsideração cotidianas realizadas pela diretora e por parte dos professores eram constantemente retomadas por Rosa.

A questão posta por Das sobre como o passado coexiste com o presente por meio da atuação da memória (Das, 2020, p. 151) é pertinente para refletirmos sobre como o sofrimento e a dor causados em outros momentos estavam presentes no cotidiano de Rosa; mais do que isso, sobre como ações distantes no tempo eram cotidianamente atualizadas por novas ações e gestos de desconsideração, uma vez que Rosa permanecia na escola em questão.

Ao refletir sobre a presença do signo no indivíduo, Wittgenstein utiliza as noções de causação e influência ${ }^{6}$, bastante apropriadas para pensarmos sobre os efeitos das palavras que assediam moralmente. Ao vivenciar regularmente um signo que assedia, ou seja, ao vivenciar sua causação, o indivíduo sente a influência dele sobre si. Wittgenstein cita o movimento da alavanca que liga o ato de ler o signo ao de escutar o seu som. Se as palavras e gestos que assediam são signos inseridos em um jogo de linguagem, podemos afirmar que o mesmo movimento de alavanca liga o signo que assedia ao sentimento de desconsideração, o qual gera dor e sofrimento no indivíduo. A palavra e o gesto, que assediam moralmente, são capazes de maltratá-lo.

O duplo esforço de Rosa consistia em elaborar simultaneamente as memórias e as ações de assédio moral a que era sujeita cotidianamente: uma tarefa nada fácil. Em alguns momentos, Rosa esmorecia em seu intuito de trabalhar naquela escola. A desistência seria uma expressão do sofrimento gerado pelas ações de desconsideração vivenciadas por ela como um insulto moral sistemático (Tiba, 2014, p. 46), já que era diariamente lembrada que sua ação como coordenadora pedagógica não era reconhecida por um grupo de professores da escola. A sistematicidade dos insultos morais, aliada ao medo gerado pela precária condição no ambiente de trabalho, fragiliza o indivíduo e é a responsável pelo adoecimento e até mesmo pela desistência das atividades laborais por parte dos professores da educação básica sujeitos ao assédio moral nas escolas do Distrito Federal. indivíduos" (Fonseca, 2004, p. 23). Já sobre os rumores, ao analisarem a forma como eles contribuíram para o crescimento dos movimentos de insurgência na Índia colonial, Pamela Steward e Andrew Strathern apontam os efeitos das palavras que, no formato de rumores, são transformadas em instrumentos de poder ao serem veiculadas em meio às ações políticas, além de atuarem como catalisadores de ações violentas praticadas pelos grupos sociais em disputa (Steward; Strathern, 2004, p. 111-112). Ainda no contexto indiano, sobre os rumores que alimentaram os atentados aos sikhs em 1984, Das afirma que: "A força perlocucionária do rumor mostra quão frágil pode ser o mundo em que vivemos. O virtual é sempre mais abrangente que o real: aqui ele mostrou que imagens de desconfiança que poderiam ter sido experimentadas apenas no registro do virtual podem assumir uma forma volátil quando a ordem social é ameaçada por um evento crítico, e transformam o mundo a tal ponto que o pior torna-se não apenas possível como também provável"(Das, 2020, p. 185).

6 Wittgenstein, Investigações filosóficas, parágrafo 169. 
horroroso e hostil para mim. Em vários momentos, ali na escola, o clima era hostil e de agressividade mesmo.

Fazer Rosa rememorar tais situações por meio do diálogo, trazer a dor das profundezas à superfície, nos termos de $\operatorname{Das}^{7}$, não foi uma tarefa fácil, uma vez que seu sofrimento também era o meu. Embora a dor sentida pelo outro não residisse em mim, sentia uma dor em resposta à dor do outro, já que tinha a convicção de que este a sentia ${ }^{8}$.

Mesmo com a dor vivida por rememorar o sofrimento de outrora, os momentos de diálogo foram considerados por Rosa e por muitos interlocutores como terapêuticos. Ao se deixar a palavra circular, assim como ocorria às mulheres retratadas por Das, seu movimento das profundezas do ser à superfície e no sentido contrário transformava a passividade em agência (Das, 2020, p. 88). Se antes não era permitido falar, para Rosa o próprio falar acabou sendo parte de um processo terapêutico. A angústia de não se expressar e tal medo eram acompanhados de uma sensação de alívio por poder digerir a violência sofrida, violência esta expressa na palpitação sentida, na boca seca e no falar aflito seguido de uma pausa com os olhos amedrontados.

\section{O desejo da Rosa: a reparação moral}

Encorajada, Rosa resolveu formalizar uma queixa sobre o assédio moral perpetrado pela diretora, que foi encaminhada às instâncias superiores da escola na qual trabalhava. Rosa e a diretora foram chamadas para relatar o ocorrido, e uma proposta de acordo foi realizada pela responsável pela mediação desse conflito: se a primeira retirasse a queixa, a segunda deixaria a escola no final do ano letivo.

Então fui até aquela instância na instituição e houve a proposta indecorosa de que eu tirasse a queixa. Eu saí do prédio da L2 em direção à parada e não consegui escutar nem ver nada. Eu só pensava na reunião que tinha acabado.

Rosa não aceitou a proposta por considerá-la insuficiente. Para ela, a formalização de um pedido de desculpas pela diretora junto ao grupo de professores atenderia aos seus anseios. Mas, para a sua surpresa, após o depoimento da diretora, a instituição arquivou a queixa, finalizando-a.

Há duas considerações sobre a frustrada tentativa de Rosa de obter a reparação moral junto à instituição à qual era vinculada. $\mathrm{O}$ assédio moral é um insulto de difícil apreensão material. As palavras e gestos de desconsideração são sutis e estão inseridos em um jogo de linguagem específico. Como retratado na cena com a diretora da escola, as ações de assédio moral vivenciadas por Rosa cotidianamente dificilmente seriam apreendidas por um observador externo e menos provavelmente ainda caracterizadas como um insulto moral. Em diálogo com Mauss, Cardoso de Oliveira afirma que a percepção do insulto moral solicita a expressão
7 Das discorre sobre a dor e o sofrimento das mulheres que, no movimento de Partição da Índia em 1947, foram violentadas e, por meio do corpo, da linguagem e da vida cotidiana, transformaram os seus sentimentos em relação à violência sofrida.

8 Wittgenstein inicia a discussão sobre a expressão da sensação no jogo de linguagem no parágrafo 281 . Das, em diálogo com Wittgenstein e Stanley Cavell, apresenta uma reflexão sobre o sentir a dor do outro (Das, 2020, p. 68-70). 
obrigatória dos sentimentos pelos envolvidos (Cardoso de Oliveira, 2011, p. 113). Nesse sentido, se os demais professores apreendessem a emoção do insulto moral sofrido por Rosa, identificar-se-iam com o seu ressentimento e compartilhariam o significado da experiência vivida por ela. Compreenderiam também que o seu ressentimento derivava de um ato intencional e indevido por parte da diretora e de um dos grupos de professores daquela escola.

É possível que o responsável pela mediação do conflito envolvendo Rosa e a diretora não tenha conseguido, por diversos motivos, identificar-se com o ressentimento daquela ou apreender a intencionalidade do ato que ela considerava insultuoso. A utilização do assédio moral como estratégia de gestão institucional pode ser um dos motivos da negação da queixa. É importante atentar para como determinados agentes institucionais incorporam as práticas de assédio moral e as vivenciam cotidianamente. Já alguns professores da escola reconheceram o sofrimento dela e o porquê das reclamações que, à época, eram constantes. Rosa recebera manifestações individuais de apoio, sempre às escondidas, mas nunca uma fala pública em repúdio ao assédio moral sofrido por ela. Mais forte do que a expressão do ressentimento vivenciado por Rosa foi o silêncio compartilhado pelos demais professores. Tratando-se de um interdito, o não falar publicamente sobre a violência sofrida pela professora expressava o medo de alguns professores de serem os próximos assediados moralmente. Não poderiam cometer o mesmo "erro" de Rosa: acusar um grupo de professores; nem a defender publicamente.

Com o arquivamento de sua queixa, Rosa não obteve o reconhecimento por parte da instituição do assédio moral sofrido. Não obteve as desculpas formais da diretora em um ato de reparação moral tão almejado por ela. Alguns meses antes do final do ano letivo, suas atividades foram encerradas na escola. Durante alguns meses, Rosa falava incessantemente sobre a perseguição a que fora submetida e sobre sua "expulsão" da escola - um processo muito doloroso para ela.

Com o passar do tempo, as ações de perseguição foram internalizadas e incorporadas ao seu modo de ser. Cenas vividas e palavras escutadas que, subitamente, vinham à tona mentalmente passaram a ser acompanhadas do silêncio e do respirar fundo. Aprendera a conviver com as marcas inscritas pelo assédio moral.

\section{Considerações finais}

O assédio moral no trabalho é uma temática contemporânea presente entre grupos de professores da instituição de educação básica em questão e outras categorias laborais do Distrito Federal. A pesquisa etnográfica realizada em consonância com a leitura da teoria antropológica traz à tona as particularidades do assédio moral entre tais professoras e professores, em um local e tempo determinados. Na busca pela compreensão de outras maneiras de ser, estar e vivenciar o mundo, a etnografia possibilita-nos apreender os desdobramentos da categoria "assédio moral" no cotidiano das escolas do Distrito Federal e suas nuanças entre grupos de professores da educação básica. 
Por meio da história da professora Rosa, é importante se atentar para a utilização do assédio moral como uma relevante ferramenta política na disputa pelos espaços institucionais e poderes entre professores da educação básica da capital administrativa do país, a qual é acionada de acordo com a conveniência dos interesses dos grupos envolvidos em tais disputas e com a conjuntura política.

Ao discordar das práticas usuais na escola e expressar tal discordância publicamente, a professora Rosa fez algo inaceitável dentro da gramática da política local. Não poderia ter exposto as práticas "erradas" dos demais professores e, por isso, passou a ser exposta às ações de assédio moral, já que não fazia parte do grupo que estava à frente da direção da escola. Sua saída da instituição ocorreu no momento oportuno para esse grupo no qual, em meio à "dança das cadeiras", não havia mais espaço para Rosa.

Sua história traz à tona o fato do assédio moral enquanto uma expressão das "violências da vida cotidiana" (Kleinman, 2000, p. 228) presentes nas escolas do Distrito Federal, lembra-nos quais são as regras morais locais vigentes e demonstra, por meio das suas ações, a força dos grupos exercida sobre algumas professoras e professores, decorrendo daí o medo compartilhado por parte dos profissionais da educação básica de serem os próximos assediados moralmente.

Entre alguns professores da educação básica do Distrito Federal, as disputas cotidianas são realizadas por meio de palavras, gestos e ações assediantes que geram sofrimento, dor e, muitas vezes, o adoecimento dos que são submetidos ao assédio moral. 


\section{Referências:}

APPADURAI, Arjun. Disjuncture and difference in the global cultural economy. In: INDA, Jonathan Xavier; ROSALDO, Renato (Eds.). The Anthropology of Globalization. A Reader. London: Blackwell, 2002. p. 46-64.

BOEHM, Cristopher. Blood revenge: the enactment and management of conflict in Montenegro and other tribal societies. Philadelphia: University of Pennsylvania Press, 1984.

BORGES, Antonádia. Tempo de Brasília: etnografando lugares-eventos da política. Rio de Janeiro: Relume Dumará, 2003.

CARDOSO DE OLIVEIRA, Luís Roberto. Direito legal e insulto moral: dilemas da cidadania no Brasil, Quebec e EUA. Rio de Janeiro: Garamond, 2011.

CARDOSO DE OLIVEIRA, Luís Roberto. Existe violência sem agressão moral? Revista Brasileira de Ciências Sociais, v. 23, n. 67, p. 135-193, 2008.

CAVALCANTI, Marilda do Couto. Estudos sobre educação bilíngue e escolarização em contextos de minorias linguísticas no Brasil. D.E.L.T.A. - Revista de Documentação de Estudos em Linguística Teórica e Aplicada, v. 15, n. especial, p. 385-417, 1999.

DAS, Veena. Vida e palavras: a violência e sua descida ao ordinário. São Paulo: Editora da Unifesp, 2020.

ERICKSON, Frederick. Metodos cualitativos de investigación sobre la enseñanza. In: WITTROCK, Merlin C. La investigación de la enseñanza, II: métodos cualitativos y de observación. Madrid: Ediciones Paidos, 1986. p. 195-301.

FAIRCLOUGH, Norman. Language and power. United Kingdom: Longman Group, 1989.

FAVRET-SAADA, Jeanne. Ser afetado, de Jeanne Favret-Saada. Revista Cadernos de Campo, n. 13, p. 155-161, 2005.

FONSECA, Cláudia. Família, fofoca e honra: etnografia de relações de gênero e violência em grupos populares. Porto Alegre: Editora da UFRGS, 2004.

HIRIGOYEN, Marie-France. Assédio moral: a violência perversa no cotidiano. Rio de Janeiro: Bertrand Brasil, 2009.

HOLSTON, James. Cidade modernista: uma crítica de Brasília e sua utopia. São Paulo: Companhia das Letras, 1993.

KLEINMAN, Arthur. The violences of everyday Life. In: DAS, Veena; KLEINMAN, Arthur; RAMPHELE, Mamphela; REYNOLDS, Pamela (Eds.). Violence and subjectivity. London: University California Press, 2000. p. 226-241.

SILVA, Aracy Lopes da Silva. A educação indígena entre diálogos interculturais e multidisciplinares. In: SILVA, Aracy Lopes da; FERREIRA, Mariana Kawall Leal (Orgs.). Antropologia, História e Educação: a questão indígena e a escola. São Paulo: Global, 2001.

STEWARD, Pamela J.; STRATHERN, Andrew. Witchcraft, sorcery, rumors and gossip. New York: Cambridge University Press, 2004.

TIBA, Thaisa. Loucas, certinhos ou incompetentes: uma etnografia do assédio moral entre professoras e professores do Distrito Federal brasileiro. Dissertação (Mestrado em Antropologia), Universidade de Brasília, Brasília, 2014.

TSING, Anna Lowenhaupt. Friction: an ethnography of global connection. Princeton; Oxford: Princeton University Press, 2005. 
Thaisa Marilia Coelho Tiba

WEBER, Max. A ética protestante e o espírito do capitalismo. São Paulo: Companhia das Letras, 2004.

WITTGENSTEIN, Ludwig. Investigações filosóficas. São Paulo: Nova Cultural, 1999. 